\title{
A STUDY OF WORK LIFE BALANCE AMONG TEACHERS
}

\author{
Ms. Nidhi A. Thakor \\ Ph.D. Research Scholar VNSGU, Surat \\ Dr. S. Balasubramanian \\ Associate professor in Commerce \\ Government College, Daman - 396210 (UT of DNH and DD)
}

\begin{abstract}
:
Human resource departments have to deal with various policies, plans, and programs to help their employees to balance their work and family for success in their lives. The present paper envisioned to study to comprehend work life balance of school teacher of Umargam in Gujarat. The study collected data from 114 school teachers. Data analysis considers statistical techniques to test the hypotheses by ANOVA, T-test, and Pearson Correlation use to analysis relationship between work life balance and job productivity. The research attained a positive correlation between work life balance and job productivity among the school teachers. However, the institution and management of the school be aware that if employees' work life balance affects, it will affect their job productivity.

Keywords: work life balance, school teachers, human resource department, job productivity

\section{Introduction:}

Work life balance is all about organizing time to give attention to work, family, and self. In the $21^{\text {st }}$ century, the notion of work life balance has gained acceptance in management, in general, and in human resource management.

Work life balance, defined as a state of well-being that allows people to handle numerous tasks, has emerged as a vital factor in achieving individual and organizational success. Work life balance is best accomplished when an individual's right to a fulfilling life, both within and outside of paid work and non-paid work, is understood and acknowledged as the norm and recognized as benefiting the individual, the business, and society.

The benefits of work life balance for employees and employers are that it helps to increase enthusiasm among employees, enhances their productivity at work, and allows them to alleviate their stress by spending leisure time with their nearest and dearest. They maintain healthy habits by having a decent work life balance with a good diet and regular workouts.

Work life balance helps individuals to cope up with overtime at work and personal commitments. Highly motivated employees can benefit an organization because they are more dedicated to pursuing their job and careers. Work life balance also helps employers to enhance jobs productivity within their organization. All individuals have to plan their day and activities to balance their work and life by prioritizing work, having flexible working hours, working from home when necessary, avoiding that waste time, scheduling sufficient time for relaxation,
\end{abstract}


organized housework, creating a work leisure plan, plan for a vacation, spending time with family and loved ones.

Positive work life balance impacts many aspects of life, including job satisfaction, family satisfaction, life satisfaction, job productivity, happiness, stress reduction, and wellbeing. Work life balance will be difficult without family and organizational support. If the organization expects to retain their employees, it must provide flexibility in work and facilities.

\section{Literature review:}

According to Padma and Reddy (2013) a studied carry out on the impact of child care responsibility on work life balance among school teachers and found that the age and number of children do not influence the work life balance among school teachers, whereas child care support from spouse and elderly parent/ in-law have a strong influence on the work life balance among school teachers. The study suggested that family members have to be willing to support women to help them to balance their work and personal life. Similarly, school management also needs to provide child care facilities such as crèches at the workplace.

Nayeem and Tripathy $(2012)^{\mathrm{b}}$ carried out a study on work life balance among 152 teachers of technical institutions of Hyderabad Municipals Corporation limits. The study found that job satisfaction negatively correlates with turnover intentions, while work life imbalance and burnout positively correlate with job satisfaction. Female teachers felt less burnout compared to male teachers.

Ajay Attri and Neelam $(2016)^{\mathrm{c}}$ carried out a study on 480 married female graduate teachers, and found that a significant difference in work-family conflict of married female graduate teachers exists to their family income and spouse occupational status. In contrast, no significant difference was found in the work-family conflict of married female graduate teachers regarding their family support.

Jain $(2013)^{\mathrm{d}}$ conducted study on work life balance index of 100 professionals and found that the existence of different levels of work life balance among Chartered Accountants, Doctors and Teachers. The study suggested that all professional need support from the organizations, family and the individuals to maintain the work life balance.

Singh and Koradia (2017) ${ }^{\mathrm{e}}$ studied found that women working in banks and school were psychologically more stable in their overall work life balance than women working in colleges and IT companies due to high work pressure and long working hours at the workplace.

Matheswaran and Hemalatha (2015) ${ }^{\mathrm{f}}$ did study on work life balance of 120 women employees in a public and private school in Tiruvllur district. The study found that private sector schools work more at home and the office than public sector school teachers. The study also reveals that both the sector teachers have difficulty finding quality time with family or friends due to work pressure and feel tired and depressed due to workload.

Singal and Parvesh $(2015)^{\mathrm{g}}$ studies on work life balance among female faculties of Hisar. Sample size of the study was 30 respondents. The study found that most faculties were not happy with the working hours and fell normal stress in managing work life and family life. The study suggested that female faculties have to adopt some systematic approach to design and implement policies to assist their own work life balance, which would help to improving their performance. 


\section{Methodology:}

This study is a quick response survey, descriptive in nature, based on the primary data collected through structured questionnaires from the randomly selected school teachers from Umargam (Gujarat). The sample size of the study is 114. Pearson Correlation coefficient was analysis to understand the co-relationship and to test hypotheses by Anova and T-test used.

\section{Objective of the study:}

- To comprehend the level of work life balance with demographic factors among the school teacher of Umargam.

- To identify the influence of work life balance on job productivity.

\section{Hypothesis of the study:}

- $\mathrm{H}_{0}$ : There is no significant impact on work life balance by the age of the respondents.

- $\mathrm{H}_{0}$ : There is no significant impact on work life balance by gender of the respondents.

- $\mathrm{H}_{0}$ : There is no significant impact on work life balance by marital status of the respondents.

- $\mathrm{H}_{0}$ : There is no significant impact on work life balance by type of family of the respondents.

- $\mathrm{H}_{0}$ : There is no significant impact on work life balance by the annual income of the respondents.

- $\mathrm{H}_{0}$ : There is no significant impact on work life balance by working hours of the respondents.

- $\mathrm{H}_{0}$ : There is no significant impact on job productivity due to work life balance.

\section{Data analysis and interpretation}

The number of respondents, Percentages, ANOVA, T-test, and Correlation test are the statistical tools applied for the study with the help of SPSS for data analysis. The hypotheses test and their interpretation were presented in the study.

\section{Age of the respondents}

The distribution of respondents in various age groups as identified viz., those below 25 years of age, in the age group between 26 - 35 years, belong to 36 - 50 years of age and above 51 years of age is presented in Table No. 1.

Table No. 1: Age of the Respondents

\begin{tabular}{|c|c|c|}
\hline Age (Years) & Number of respondents & Percent \\
\hline Below 25 & 11 & 10 \\
\hline $26-35$ & 57 & 50 \\
\hline $36-50$ & 40 & 35 \\
\hline Above 51 & 6 & 5 \\
\hline Total & 114 & 100 \\
\hline
\end{tabular}


Table No. 1 shows that most of the respondents belong to the age group 26 - 35 years. A considerable percent of 35 percent of the respondents are in the middle age group, i.e., 36 50 years.

- $\mathrm{H}_{0}$ : There is no significant impact on work life balance by the age of the respondents.

Table 2 the results shows with one-way Anova test. The respondents' work-life balance and age group reveal that the P-Value is 0.443 , which is more than 0.05 . Thus null hypothesis is accepted and conclude that there is no significant impact on work life balance by the age of the respondents.

Table No.: 2 Work Life Balance and Age - ANOVA TEST

\begin{tabular}{|c|c|c|c|c|c|}
\hline & Sum of Squares & Df & Mean Square & F & Sig. \\
\hline Between Groups & 143.585 & 3 & 47.862 & & \\
\cline { 1 - 4 } Within Groups & 5846.380 & 110 & 53.149 & \multirow{2}{*}{901} & \multirow{2}{*}{0.443} \\
\hline Total & 5989.965 & 113 & & & \\
\hline
\end{tabular}

\section{Gender of the respondents}

For this study, sample respondents of school teachers are grouped into two categories: Female and Male. This information is presented in Table No. 3.

Table No.: 3 Gender of the Respondents

\begin{tabular}{|c|c|c|}
\hline Gender & Number of respondents & Percent \\
\hline Female & 86 & 75 \\
\hline Male & 28 & 25 \\
\hline Total & 114 & 100 \\
\hline
\end{tabular}

Table 3 denotes that 75 percent of the respondents belong to the female categories.

- $\mathrm{H}_{0}$ : There is no significant impact on work life balance by gender of the respondents.

Table 4 showed the T-test to show the significant impact on work life balance. The results describe that P-Value is 0.000 , which is less than 0.05 . Hence null hypothesis was rejected and concluded that there is a significant impact on work life balance by gender of the respondents.

Table No.: 4 Work Life Balance and Gender - T-test

\begin{tabular}{|c|c|c|c|c|c|}
\hline Gender & N & Mean & S.D & Df & Sig. \\
\hline Female & 86 & 31.91 & 6.480 & \multirow{2}{*}{112} & \multirow{2}{*}{0.000} \\
\cline { 1 - 5 } Male & 28 & 41.86 & 3.493 & & \\
\hline
\end{tabular}

\section{Marital status of the respondents}

For this present study, the marital status of the respondents was grouped into two groups viz., single and married. Table 5 shows that 77 percent of the respondents are married, and only 23 percent are single. 
Table No.: 5 Marital Status of the Respondents

\begin{tabular}{|c|c|c|}
\hline Marital Status & Number of respondents & Percent \\
\hline Single & 26 & 23 \\
\hline Married & 88 & 77 \\
\hline Total & 114 & 100 \\
\hline
\end{tabular}

- $\mathrm{H}_{0}$ : There is no significant impact on work life balance by marital status of the respondents.

Table 6 indicates that the T-test used to test the hypothesis and results show that PValue is 0.500 , more than 0.05 . Hence the null hypothesis accepted and concluded that there is no significant impact on work life balance by marital status of the respondents.

Table No.: 6 Work Life Balance and Marital Status - T-test

\begin{tabular}{|c|c|c|c|c|c|}
\hline Marital status & $\mathbf{N}$ & Mean & Std. Deviation & Df & Sig. \\
\hline Single & 26 & 33.50 & 7.638 & \multirow{2}{*}{112} & \multirow{2}{*}{0.500} \\
\cline { 1 - 4 } Married & 88 & 34.60 & 7.198 & & \\
\hline
\end{tabular}

4. Type of family of the respondents

This divide into two categories, i.e., nuclear family and joint family.

Table 7 reveals that most of the respondents were living in a joint family.

Table No.: 7 Type of Family of the Respondents

\begin{tabular}{|c|c|c|}
\hline Type of Family & Number of respondents & Percent \\
\hline Nuclear & 41 & 36 \\
\hline Joint & 73 & 64 \\
\hline Total & 114 & 100 \\
\hline
\end{tabular}

- $\mathrm{H}_{0}$ : There is no significant impact on work life balance by type of family of the respondents.

Table 8 indicates that the T-test results P-Value is 0.028 , which is less than 0.05 . Hence the null hypothesis is rejected and concludes that there is a significant impact on work life balance by type of respondents' family.

Table No.: 8 Work Life Balance and Type of Family - T-test

\begin{tabular}{|c|c|c|c|c|c|}
\hline Type of family & $\mathbf{N}$ & Mean & Std. Deviation & Df & Sig. \\
\hline Nuclear & 41 & 32.37 & 7.286 & \multirow{2}{*}{112} & \multirow{2}{*}{0.028} \\
\hline Joint & 73 & 35.47 & 7.085 & & \\
\hline
\end{tabular}

\section{Annual Income of the respondents}

The employees' annual income is classified under four categories: up to ` 1 lakh, ` 1 to 2 lakh, ' 2 to 3 lakh, and more than ` 3 lakh.

Table No.: 9 Annual Income of the Respondents

\begin{tabular}{|c|c|c|}
\hline Annual Income & Number of respondents & Percent \\
\hline Up to 1 lakh & 53 & 46 \\
\hline 1 lakh-2 lakh & 40 & 35 \\
\hline
\end{tabular}




\begin{tabular}{|c|c|c|}
\hline 2 lakh-3 lakh & 9 & 8 \\
\hline More than 3 lakh & 12 & 11 \\
\hline Total & 114 & 100 \\
\hline
\end{tabular}

From Table No. 9, it is observed that a majority of the respondents were 46 percent were earning up to ` 1 lakh, the lowest income slab, than 35 percent were earning 1 lakh to 2 lakh and 11 percent were earning more than 3 lakh.

- $\mathrm{H}_{0}$ : There is no significant impact on work life balance by the annual income of the respondents.

Table No. 10 result shows that Anova test results where P-Value is 0.004, less than 0.05 . Thus the null hypothesis was rejected and conclude that there is a significant impact on work life balance by the annual income of the respondents.

Table No.: 10 Work Life Balance and Annual Income - ANOVA

\begin{tabular}{|c|c|c|c|c|c|}
\hline & Sum of Squares & Df & Mean Square & F & Sig. \\
\hline Between Groups & 684.278 & 3 & 228.093 & & \\
\cline { 1 - 4 } Within Groups & 5305.686 & 110 & 48.234 & \multirow{2}{*}{4.729} & .004 \\
\hline Total & 5989.965 & 113 & & & \\
\hline
\end{tabular}

\section{Working hour of the respondents}

For the study purpose, the working hours at the workplace are classified into three categories, i.e., 6 hours, 7 hours, and 8 hours.

Table No.: 11 working hours

\begin{tabular}{|l|l|l|}
\hline Working Hours & Number of respondents & Percent \\
\hline 6 hours & 76 & 66 \\
\hline 7 hours & 26 & 23 \\
\hline 8 hours & 12 & 11 \\
\hline Total & $\mathbf{1 1 4}$ & $\mathbf{1 0 0}$ \\
\hline
\end{tabular}

Table No.11 shows that 66 percent of the respondents spent 6 hours, 23 percent spent 7 hours, and 11 percent spent 8 hours at the workplace.

- $\mathrm{H}_{0}$ : There is no significant impact on work life balance by working hours of the respondents.

Table 12 result shows that the Anova test where the P-Value is 0.429 , which is more than 0.05 . Thus the null hypothesis accepted and concluded that there is no significant impact on the work life balance by working hours.

Table No.: 12 Work Life Balance and Working Hours - ANOVA

\begin{tabular}{|c|c|c|c|c|c|}
\hline & Sum of Squares & df & Mean Square & F & Sig. \\
\hline Between Groups & 90.679 & 2 & 45.339 & .853 & 0.429 \\
\hline
\end{tabular}




\begin{tabular}{|c|l|l|l|l|l|}
\hline Within Groups & 5899.286 & 111 & 53.147 & & \multirow{2}{*}{} \\
\cline { 1 - 4 } Total & 5989.965 & 113 & & & \\
\hline
\end{tabular}

\section{Work Life Balance and Job Productivity}

From Table No.13, the result reveals the existence of the relationship between job productivity and work life balance. The Correlation between job productivity and work life balance is the strongest to the extent of 0.861 . A positive correlation is found. There is a strong positive Correlation between work life balance and job productivity.

Table No.: 13 Work Life Balance and Job Productivity - Correlation

\begin{tabular}{|l|c|c|}
\hline & Work life balance & Job productivity \\
\hline Work life balance Pearson correlation & 1 & $.861^{* *}$ \\
Sig. (2-tailed) & & .000 \\
$\mathrm{~N}$ & 114 & 114 \\
\hline Job productivity Pearson Correlation & $.861^{* *}$ & 1 \\
Sig. (2-tailed) & .000 & \\
$\mathrm{~N}$ & 114 & 114 \\
\hline
\end{tabular}

** Correlation is significant at the 0.01 level (2-tailed)

The result shows that job productivity is directly proportional to work life balance, which means that a healthy work life balance can increase the overall performance and the job productivity of the school teachers, whereas imbalanced work life can lead to poor job productivity among school teachers.

\section{Conclusions:}

The result of the study shows a greater degree of Correlation between work life balance and job productivity. The study also found that the demographic factor of the respondents (Age, Marital status, and Working hours) have no impact on work life balance. Whereas Gender, Type of family, and annual income significantly impact school teachers' work life balance.

\section{References}

as. Padma and M. Sudhir Reddy, (2013) "Impact of Child Care Responsibility on Work Life Balance (WLB) of School Teachers," International Journal of Advanced Research in Business Management and Administration Vol. 1 Issue. 1 pp 57- 63.

${ }^{b}$ M. Nayeem and M. Tripathy, (2012) "Work-Life Balance among Teachers of Technical Institutions," The Indian Journal of Industrial Relations, Vol. 47, Issue 4, pp 724-736.

${ }^{c}$ Ajay Attri and Neelam, (2016) "Work-Family Conflict of Married Female Teachers in Relation to Family Related Variables," Scholarly Research Journal's for Interdisciplinary Studies, Vol. 4, Issue 27, pp 4354-4361.

'Pratyasha Jain, (2013) "A Comparative Study of Work Life Balance among CA, Doctors, and Teachers," International of Multidisciplinary Research in Social \& Management Sciences, Vol.1, Issue 4, pp 58-65. 
${ }^{\text {e}}$ Shefali Singh and Dr. Kavita Koradia, (2017) "Psychological Well Being and Work-Life Balance of Working Women - A co-relational study," International Journal of Scientific \& Engineering Research, Vol. 8, Issue 12, pp 1935- 1940.

${ }^{\mathrm{f}}$ Dr. V. P. Matheswaran and V. Hemalatha, (2015) "A Study on Work Life Balance for Women Employees in Public and Private Sector School in Tiruvllur District", International Journal of Research in Management and Technology, Vol. 5, Issue 1, pp 196-206.

sRahul Singal and Parvesh (2015) "Work Life Balance of Women Employees with Reference to Teaching Faculties" International Journal of Research in Management, Science and Technology, Vol. 3, Issue 3, pp 53-56. 